\title{
Glass and glass-ceramic coatings, versatile materials for industrial and engineering applications
}

\author{
AMITAVA MAJUMDAR* and SUNIRMAL JANA \\ Glass-Ceramic Coating Division, Central Glass and Ceramic Research Institute, Calcutta 700 032, India
}

MS received 20 July 2000; revised 18 October 2000

\begin{abstract}
Among various coating systems for industrial and engineering applications, glass and glass-ceramic coatings have advantages of chemical inertness, high temperature stability and superior mechanical properties such as abrasion, impact etc as compared to other coating materials applied by thermal spraying in its different forms viz. PVD, CVD, plasma, etc. Besides imparting required functional properties such as heat, abrasion and corrosion resistance to suit particular end use requirements, the glass and glass-ceramic coatings in general also provide good adherence, defect free surface and refractoriness.

Systematic studies covering the basic science of glass and glass-ceramic coatings, the functional properties required for a particular end-use along with the various fields of application have been reviewed in this paper.
\end{abstract}

Keywords. Wear; glass and glass-ceramic coatings; enamelling; coating properties.

\section{Introduction}

Modern technology uses a number of surface coating materials applied using technologies viz. PVD, CVD, plasma, etc for different industrial and engineering applications (Burgel and Kvernes 1986). Among various coating systems, oxide coatings provide additional advantage of chemical inertness, high temperature stability and superior mechanical properties as compared to other nonoxide coatings currently in use e.g. metals, polymers, paints, rubbers, etc (Majumdar and Ganguli 1995). Often, the coating systems are engineered for selectively very specific end use requirements. Modern engineering technology, now demands some coatings which should also have a broad spectrum of effectivity under a range of hostile environments. In recent years, dramatic improvements in property of the glass-ceramic coating systems have been achieved by tailoring the microstructure of the glassy oxide coating matrix either by addition of secondary phases or by in situ crystallization of glassy oxide coating after application. Besides required functional properties to suit particular end use requirements, the coating in general need to possess good adherence, defectfree smooth surface and refractoriness (Miller et al 1986). A systematized information in this particular field is insufficient and a comprehensive coverage of required information in general which benefits future research is scanty. An attempt has therefore been made here to depict in some systematic way information on glass and glass-

*Author for correspondence ceramic coatings that are suited to industrial and engineering applications.

\section{Wear}

With the changing industrial climate of the country, the productivity level of the different industrial units is one of the key factors to remain competitive both nationally and internationally. Productivity being the pivotal point, it is absolutely essential to ensure uninterrupted production in the industries by proper maintenance of the machinery/ equipment for their mere survival. One of the main reason (Tong et al 1998) for shutting down of units like thermal power station, jute/textile mills, slurry transportation systems, etc is the high wear rates of their components. Minimized wear would not only contribute directly to the reduction of unit cost of components but also downtime reduction.

Wear, in general, is a gradual digressive process, whereas fracture occurs as a sudden failure (Hocking et al 1989).

In a study conducted in late eighties, it was reported that cost (Briggs 1989) of wear in UK was $\sim \$ 100$ billion/ year, in Germany, it was estimated to be about $\$ 260$ billion/ year and in USA, only erosion of metals were estimated to be about $\$ 700$ billion/year. Unfortunately no specific data (Narang 1998) is available for India.

Thus wear in general may be considered as damage to a solid surface involving progressive loss of materials either due to sliding effect with another contacting surface or due to chemical attack in corrosive/high temperature environ- 
ment. Depending on its nature, the wear can be one of the following four types (Maskal and White 1986) viz. adhesive, abrasive, erosive and corrosive.

\subsection{Strategy to reduce wear}

The strategy to reduce (Maskal and White 1986) wear is to first change the material of the component to those that have higher hardness, higher strength and long survivals. However, the option is not always feasible because of the following reasons: (i) it is not cost-effective in many situations and (ii) the concerned component is so complicated in shape and design that technically it is not feasible to change the material.

The other strategy will be to modify the surface (Hennicke and Pandel 1991) so that it has higher hardness. This can be done through surface diffusion of materials or alternately by applying a coating on the surface. The coating can be of a polymer or of a glass-ceramic. The advantage of a glass-ceramic coating is that it is chemically inert, can withstand high temperature (up to $\sim 1000^{\circ} \mathrm{C}$ ) and has superior mechanical properties compared to polymer and other non-oxide coatings, viz. paints, metals, rubbers, etc. Polymers can generally withstand a temperature of $\sim 250^{\circ} \mathrm{C}$ and in rare instances, it can go up to $400^{\circ} \mathrm{C}$. A glass ceramic coating (table 1) often allows more flexibility in design as it can withstand much wider mechanical and thermal abuses (CGCRI Training Manual 1993).

\section{Glass and glass-ceramic}

Vitreous enamels are defined as glossy inorganic composition which adhere to metals by fusion and protect them against corrosive conditions (Andrews 1962). In recent years, end use requirements have dictated the need for special coating materials with much superior properties than conventional enamels. Such coatings provide protection of the metal against high temperature and corrosive atmosphere and are commonly called glass-ceramic coatings. These are distinguished from conventional vitreous enamel coatings by the presence of suitable amounts of microcrystallites uniformly distributed in a glassy phase constituting the coating (figure 1) (McMillan 1978). The crystalline phases are produced by nucleation and crystal growth from and within the glassy phase coating material by suitable heat treatment process, so as to provide the unique combination of properties viz. high degree of resistance towards abrasion, impact, high temperature, chemical corrosion and thermal shock to prevent the failure of the substrate metals under stringent operational conditions.

Glass-ceramic materials are polycrystalline solids prepared by controlled crystallization of glass. Crystallization is accomplished by subjecting the glass composition to carefully regulated heat treatment schedule which results in the nucleation and growth of crystalline phases within the glass. The homogeneity of parent glass together with controlled conditions under which the crystals are developed, result in glass-ceramic materials having a very fine grained uniform structure free from porosity. This helps in developing high mechanical strength and good electrical insulation properties (McMillan 1978). Addition of fillers such as $\mathrm{Al}_{2} \mathrm{O}_{3}, \mathrm{ZrO}_{2}, \mathrm{Cr}_{2} \mathrm{O}_{3}, \mathrm{Fe}_{2} \mathrm{O}_{3}$ and $\mathrm{NiO}$ in the coatings increase their adherence to the substrate as well as help control their porous microstructure (Zubekhin et al 1996).

Crystallization is the method by which a glass can be transformed into a glass-ceramic material. Thus, crystallization is the process by which the regular lattice of the crystal is generated from the less ordered amorphous, super critical liquid structure. In its simplest form, crystallization is observed when a melt of single pure (a)

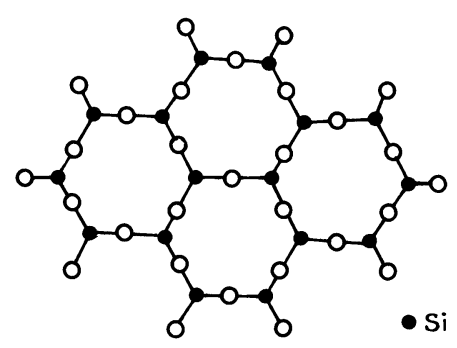

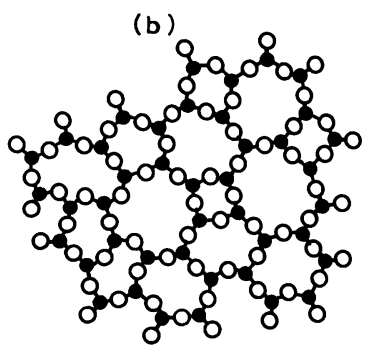

O Oxygen
Figure 1. (a) Crystalline material (regular) and (b) glassy material (irregular).

Table 1. Physico-chemical properties of different coating materials.

\begin{tabular}{|c|c|c|c|c|c|}
\hline Properties & $\begin{array}{c}\text { Glass-ceramic } \\
\text { coating }\end{array}$ & $\begin{array}{l}\text { Stainless } \\
\text { steel }\end{array}$ & Plastic & $\begin{array}{l}\text { Anodized } \\
\text { aluminium }\end{array}$ & $\begin{array}{c}\text { Stoving } \\
\text { paint }\end{array}$ \\
\hline Colour performance & Very good & Poor & Good & Poor & Good \\
\hline Cleanliness & Excellent & Very good & Fair & Fair & Fair \\
\hline Resistance to heat and light & Excellent & Excellent & Poor & Good & Fair \\
\hline Resistance to corrosive attack & Very good & Very good & Very good & Good & Poor \\
\hline Resistance to scratch and abrasion & Excellent & Very good & Poor & Poor & Poor \\
\hline Resistance to brittleness and chipping & Good & Very good & Poor & Good & Fair \\
\hline Hygienic & Very good & Fair & Fair & Good & Poor \\
\hline
\end{tabular}


element or compound is cooled; conversion from liquid to solid state occurs at a fixed temperature for a given pressure and is known as the freezing point. Thus, if a glass composition containing suitable nucleating agents is heated from room temperature to the nucleation temperature zone, as shown in figure 2 (McMillan 1978), a large number of nuclei can be generated within the mass of glass. When glass is further heated to the crystallization temperature, crystals will grow on these nuclei leading to the transformation of the glass into a fine grained glassceramic material. The types of crystals that appear and the microstructure of the glass-ceramic depends on the initial glass composition, the nature and amounts of the nucleating agents added and on the heat treatment schedules.

\section{Purpose of glass-ceramic coating}

The purpose of using a glass-ceramic coating, as a new and versatile engineering material (Schmid and Heeht 1988), is to prevent abrasion, corrosion, thermal failure and oxidation during heat treatment. These are the primary objectives for choosing a glass-ceramic coating against all other types of available coating materials (as mentioned in table 1) and its ranges of application is shown in figure 3.

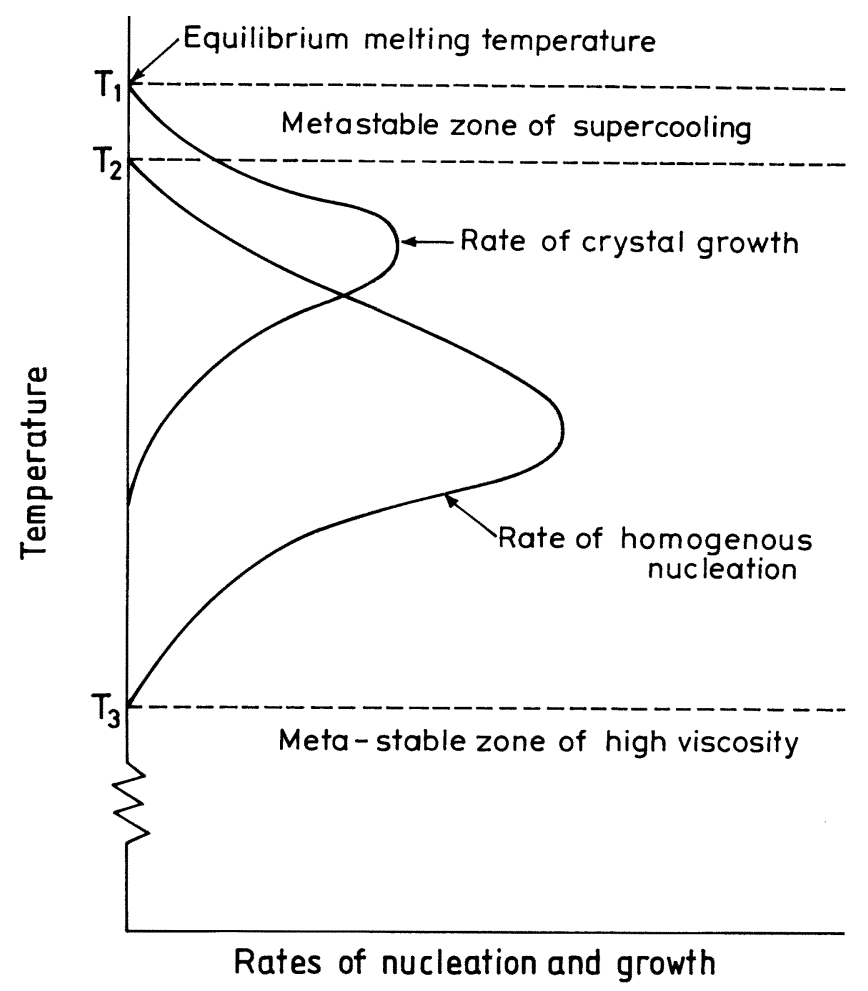

Figure 2. Nucleation and crystal growth in glass (schematic).

\section{Glass-ceramic coating and related matters in general}

Glass and glass-ceramic coating practise also known as enamelling, broadly comprises of the following steps: (i) selection of proper substrate; (ii) metal surface preparation; (iii) preparation of coating material; (iv) application of coating material; (v) drying of coating material, and (vi) maturing of the coated material.

\subsection{Selection of substrate}

Sheet iron to be selected for enamelling should conform to the following criterion (Andrews 1962): (i) low carbon content (not more than $0.2 \%$ ); (ii) freedom from harmful gases in the metal (viz. $\mathrm{CO}_{2}, \mathrm{SO}_{2}$ ); (iii) low hydrogen collection during coating or enamelling; (iv) uniform composition and structure (preferably martensitic) and freedom from solid solution (austenitic and martensitic); (v) uniform surface texture; (vi) requisite drawing and welding properties, and (vii) slag inclusion, lamination of carbide segregation should be absent in metal structure.

\subsection{Substrate preparation}

The quality of coating depends largely on the nature of the surface to which the coating is applied (Shaw 1968). The substrate here means the metal, whose surface must be cleaned and etched prior to the application of coating material. The cleaning of metal surface (Shaw 1968) can be accomplished thermally, mechanically or chemically.

\subsection{Thermal degreasing}

It is a heating operation to remove organic impurities and strain in the metal. The temperature and duration of the operation depend upon quality and size of the metallic article. The scale formed during the operation is removed

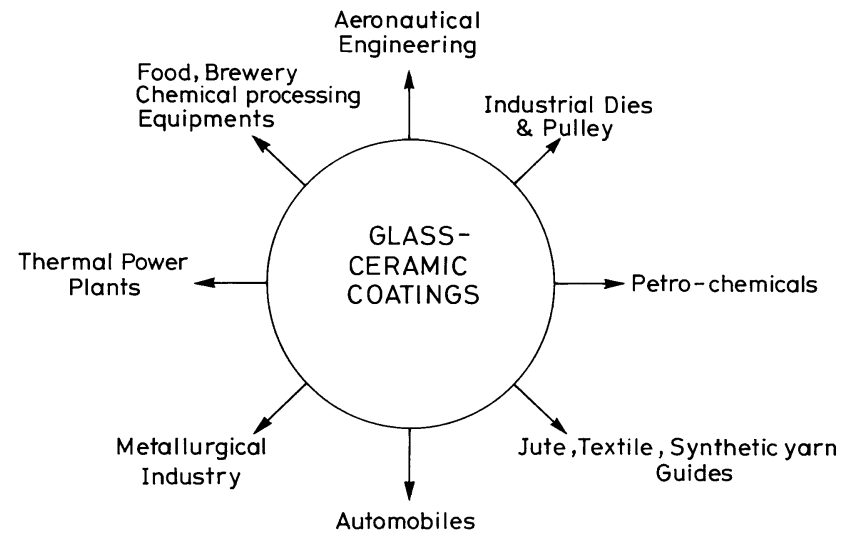

Figure 3. Areas of application of glass-ceramic coatings. 
subsequently. A close control over heat treatment schedule is essential to avoid excessive scaling.

\subsection{Mechanical cleaning}

It is done generally by blasting for large shapes or heavy stocks. The metal surface is exposed to a jet of an abrasive material such as quartz, alumina or steel shots to remove scale, rust and dirt. The surface becomes clean and slightly pitted which helps promote good bonding. Removal of material from the surface should not be excessive and is controlled by adjusting the air pressure and exposure time of blasting.

\subsection{Chemical cleaning and degreasing}

This step is carried out (Shaw 1968) to remove oil, grease and other organic impurities by using organic solvents or more commonly, alkaline solutions. The animal and vegetable fats are saponified by alkalis and the soap formed is washed off while mineral oils are removed as emulsion. Mixing/stirring of the solution and heating to $80-100^{\circ} \mathrm{C}$ accelerates the process. The $\mathrm{pH}$ of the solution should be in the range 8-13 depending on the degree of contamination. Control of solution composition and temperature is necessary to ensure proper cleaning.

After cleaning, the ware is rinsed with overflowing water for complete removal of traces of adherent cleaning solution. After this, three important steps are to be followed very cautiously in order to achieve proper coating.

\subsection{Pickling}

After chemical or thermal degreasing, the rust and scales are removed from the metal surface by immersing the articles in an acid solution. Pickling (Shaw 1968) in $\mathrm{HPO}_{4}$ improves the quality of the surface but is not practised extensively because of high cost of the acid. Generally, pickling is done either in $\mathrm{H}_{2} \mathrm{SO}_{4}$ or $\mathrm{HCl}$. The parameters to be controlled are the acid strength, iron content in solution, sludge and pickling time (which should be minimum to avoid hydrogen absorption).

\subsection{Nickel flushing}

After pickling, sometimes the metal pieces are immersed in a solution of $\mathrm{NiSO}_{4} \cdot 6 \mathrm{H}_{2} \mathrm{O}$ (Shaw 1968) in order to deposit a thin layer of metallic nickel on the metal surface which prevents fish scale and copper head formation and promotes adherence. (A $2 \%$ solution of $\mathrm{NiSO}_{4} \cdot 6 \mathrm{H}_{2} \mathrm{O}$ at a $\mathrm{pH} 3 \cdot 2-3.6$ and maintained at $65-75^{\circ} \mathrm{C}$ is generally used).

\subsection{Neutralizing}

This process removes the acidic residue adhering on the metal surface (Shaw 1968) in order to prevent rusting on the metal surface during drying. An alkaline solution used for the purpose contains $0.3-0.4 \mathrm{wt} \% \mathrm{Na}_{2} \mathrm{O}$ and is prepared by dissolving $\mathrm{Na}_{2} \mathrm{CO}_{3}$ and $\mathrm{Na}_{2} \mathrm{~B}_{4} \mathrm{O}_{7} \cdot 10 / 5 \cdot \mathrm{H}_{2} \mathrm{O}$ in the proportion of $2: 1$ in water. The operating temperature is maintained at $60-70^{\circ} \mathrm{C}$. Two neutralizing baths are generally used, the first being relatively stronger than the later.

After neutralizing, the moisture is removed from the clean metal surface by heating in a chamber at 150$200^{\circ} \mathrm{C}$. Drying should be completed quickly to avoid rusting.

\subsection{Preparation of coating materials}

After careful selection of glass and glass-ceramic coating systems suitable for desired end properties, the glass is melted and fritted. These frits (glass) are ground in a mill in dry or wet condition. During wet milling certain mill additives, usually clays and electrolytes are incorporated. A thick creamy suspension (slip) is produced for application over clean metal surface (Andrews 1962).

\subsection{Mill additives}

Plastic clays, various types of natural or synthetic gums and colloidal silica serve as suspending agents and help control the slip properties and the bubble structure of the ground coat. Electrolytes are used to adjust the set property of the slip, the common ones being $\mathrm{BaCl}_{2}, \mathrm{MgSO}_{4}$, $\mathrm{K}_{2} \mathrm{CO}_{3}$. Some refractory materials such as quartz, feldspar etc are incorporated (normally in ground coat) to increase the maturing range and workability. Opacifier and colours are often added along with other mill additions in some cover coats (Miller 1988).

The glass frits, in the form of powder (60 mesh BS sieve) is mixed with mill additives (as mentioned above) and milled to form a slip ( -200 mesh BS sieve) which is allowed to age. Finally, flowability, spreadability, setting characteristics and $\mathrm{pH}$ of the slip are measured to effectively control the slip of coating material before application (Andrews 1962).

\subsection{Application of coating material}

The common application techniques (Shaw 1968) are, dipping, slushing and spraying.

\subsection{Drying of coating material}

After application of coating slip by any one of the above processes, the coating is dried at $\sim 100^{\circ} \mathrm{C}$ (Shaw 1968). If drying is not complete, moisture removal takes place at higher temperature causing 'boiling' or 'pop-off' defects. Low clay content and coarse particle size facilitate quick drying. 


\subsection{Maturing or firing of the coated material}

Maturing or firing is the last operation in the enamelling process (Andrews 1962; Shaw 1968). The controlling parameters are as follows:

Maturing (temperature and duration) depends on the fusion characteristics of coating material and the type of metal substrate. Longer maturing time causes defects like copper heads and poor adherence (due to heavy oxidation of metal), while shorter maturing time causes pinholes, poor gloss and adherence.

The heating schedule depends on thickness and uniformity of the metal substrate, thickness of the coating, fineness of the coating material, thermal mass of the article, firing jigs to be used and ultimate end use requirement.

Uniformity in heating and cooling of the coated articles is of great importance for prevention and control of certain defects like chipping, hairlines and cracking.

The atmosphere inside the heating furnace should be dust free and oxidizing. Reducing gases like $\mathrm{CO}$ and unburnt carbon are undesirable. Normally, electrically heated muffle furnaces are used for enamel firing.

The entire process of glass and glass-ceramic coating is summarized in the flow diagram (figure 4).

\section{Properties of glass and glass-ceramic coating ma- terial}

Glass-ceramic coating material belongs to that class which is useful for specialized engineering and industrial applications. The glass-ceramic coatings possess superior coating properties as compared to conventional vitreous enamel (table 2).

Tribological evaluation of glass-ceramic coatings indicate their usefulness in sliding machine parts (figure 5), and abrasion resistance property of this type of coating indicates that they are very highly resistant towards abrasion even on prolonged use (figure 6) (Sen et al 1989).

\section{Types of glass-ceramic coatings suitable for indus- trial and engineering applications}

For industrial uses, the normal domestic enamels have some major disadvantages compared to glass-ceramic coatings which has been shown in table 3 .

A number of compositions in the system RO- $\mathrm{R}_{2}^{\prime}$ $\mathrm{O}-\mathrm{R}_{2}^{\prime \prime} \mathrm{O}_{3}-\mathrm{SiO}_{2}$ (where $\mathrm{R}=\mathrm{Ca}, \mathrm{Mg} ; \mathrm{R}^{\prime}=\mathrm{Na}, \mathrm{K}$, and $\mathrm{Li}$ and $\mathrm{R}^{\prime \prime}=\mathrm{Al}, \mathrm{B}$ ) have been studied at CGCRI (Majumdar

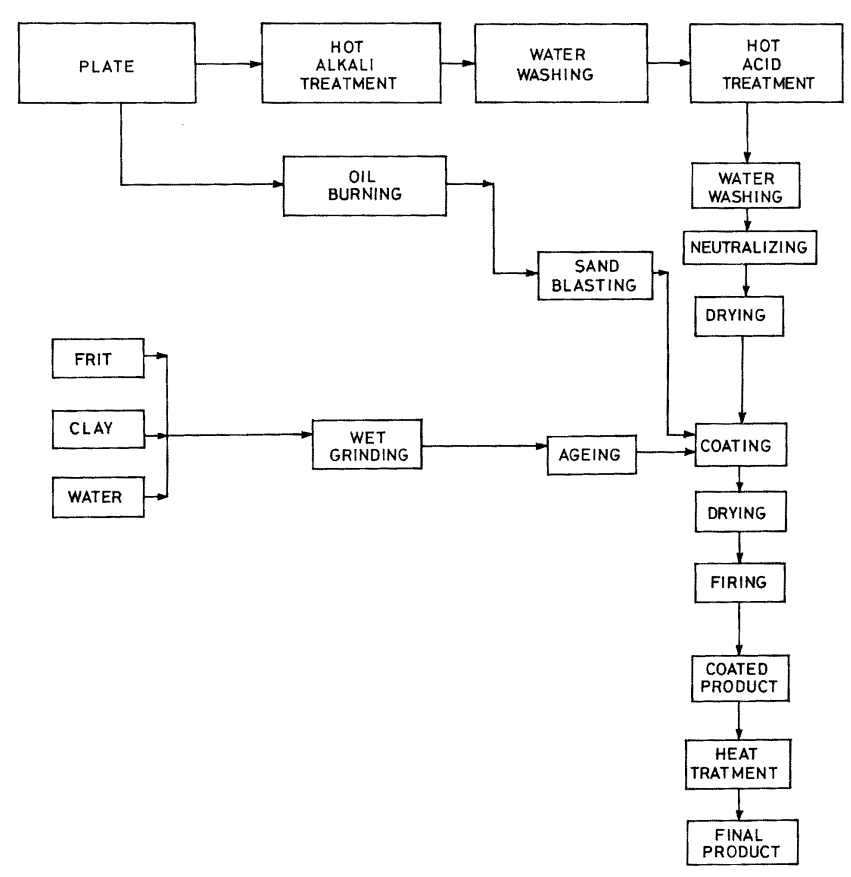

Figure 4. Flow diagram of glass-ceramic coating application on metallic substrate.

Table 2. Properties of glass-ceramic coating compared to vitreous enamel coating.

\begin{tabular}{|c|c|c|c|}
\hline \multirow[b]{2}{*}{ Properties } & \multicolumn{2}{|c|}{ Glass-ceramic coating } & \multirow{2}{*}{$\begin{array}{l}\text { Vitreous enamel } \\
\text { coating }\end{array}$} \\
\hline & Mild and stainless steel & Nimonic alloy & \\
\hline $\begin{array}{l}\text { Abrasion resistance } \\
\text { (Loss in weight value against 50,000 cycles } \\
\text { in P.E.I. abrasion tester) }\end{array}$ & $1.0-1.2 \mathrm{mg} / \mathrm{cm}^{2}$ & $0 \cdot 6-0.8 \mathrm{mg} / \mathrm{cm}^{2}$ & $4-6 \mathrm{mg} / \mathrm{cm}^{2}$ \\
\hline Impact strength (falling ball method) & $22-25 \mathrm{~kg} / \mathrm{cm}$ & $15-20 \mathrm{~kg} / \mathrm{cm}$ & $10-12 \mathrm{~kg} / \mathrm{cm}$ \\
\hline Thermal shock resistance & $\begin{array}{l}400^{\circ} \mathrm{C}(15 \text { cycles mild steel }) \\
600^{\circ} \mathrm{C}(10 \text { cycles stainless steel })\end{array}$ & $900^{\circ} \mathrm{C}(10$ cycles $)$ & $350-400^{\circ} \mathrm{C}(6$ cycles $)$ \\
\hline $\begin{array}{l}\text { Acid resistance (boiling) } \\
\text { (a) } 6 \% \text { Citric acid } \\
\text { (b) } 11 \% \text { Hydrochloric acid }\end{array}$ & $\begin{array}{c}3-6 \mathrm{mg} / \mathrm{dm}^{2} \\
30-50 \mathrm{mg} / \mathrm{dm}^{2}\end{array}$ & $25-\overline{50} \mathrm{mg} / \mathrm{dm}^{2}$ & $\begin{array}{c}6-10 \mathrm{mg} / \mathrm{dm}^{2} \\
100-150 \mathrm{mg} / \mathrm{dm}^{2}\end{array}$ \\
\hline $\begin{array}{l}\text { Alkali resistance (boiling) } \\
\text { Tetra-sodium pyrophosphate }(\mathrm{pH}=10)\end{array}$ & $3-6 \mathrm{mg} / \mathrm{dm}^{2}$ & $0 \cdot 8-1 \cdot 2 \mathrm{mg} / \mathrm{dm}^{2}$ & $15-25 \mathrm{mg} / \mathrm{dm}^{2}$ \\
\hline
\end{tabular}


and Das 1996). The glass-ceramic coatings were characterized by DTA, X-ray and SEM techniques. The X-ray studies and SEM micrographs indicate that conventional enamel coatings are generally amorphous in nature (figure 7), whereas, the glass-ceramic coatings are partially crystallized (figure 8). Various crystalline phases viz. anatase, rutile, quartz, magnesium aluminium titanate (MAT), etc are present, depending upon the system used and the heat treatment schedule followed. The volume fraction of the crystals are around $50 \%$. The particle size distribution is rather narrow as evidenced from SEM micrograph (figure 8) and it varies from $0 \cdot 5-1 \cdot 0 \mu \mathrm{m}$. The distribution of crystals is almost homogeneous (Majumdar and Jana 2000).

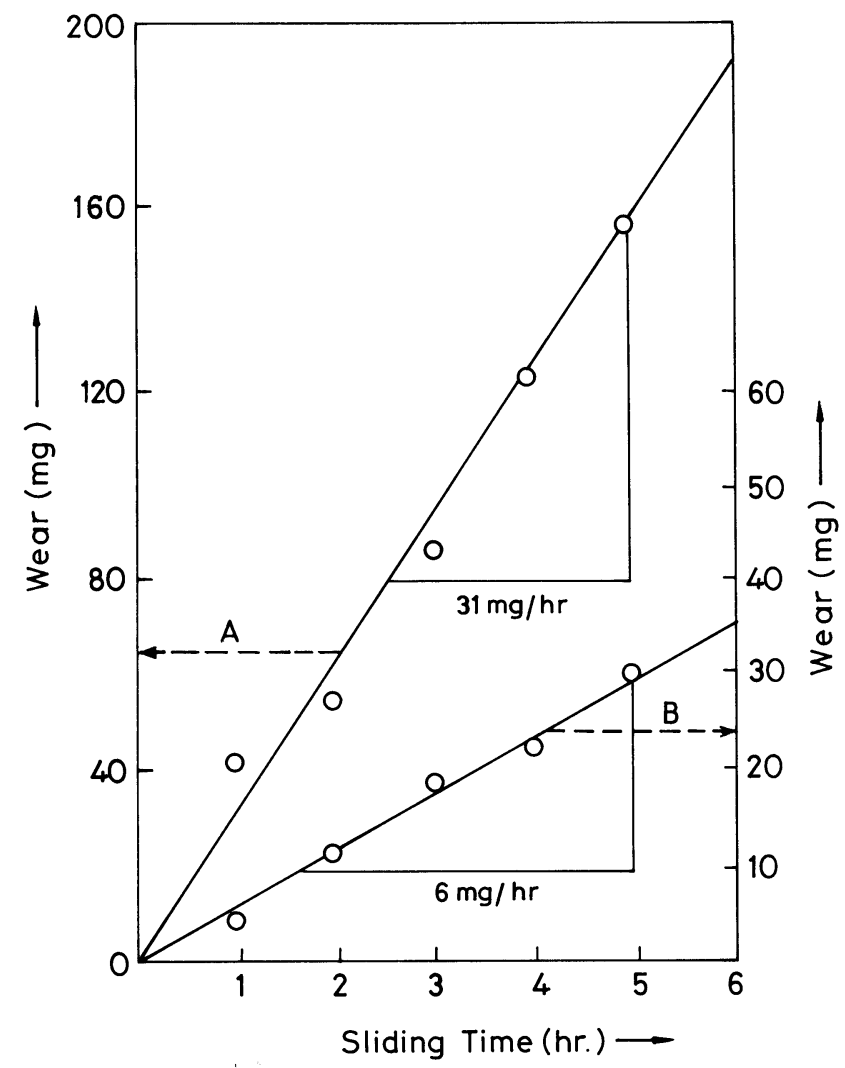

Figure 5. Wear rate of mild steel (A) and glass-ceramic coating (B) sliding against cast iron (load $6.5 \mathrm{~kg}$, velocity $45 \mathrm{~cm} / \mathrm{sec}$, contact area $5 \mathrm{~cm}^{2}$, dry environment).
In general, these glass-ceramic coating slips have excellent rheological properties and application is very easy and cost-effective too. They produce a good surface finish with a good soothing colour ranging from bluish grey to milky white. They can also be coloured using various inorganic pigments without affecting overall properties.

Now, in considering the functional use of glass-ceramic coatings, the major problem is to determine the end use requirements and to select the correct type of coating material which can withstand the service conditions. It is known that no single coating composition is necessarily the best in its resistance to all types of environments like chemical, heat and abrasion. Following are some types of coating materials suitable for respective end uses.

\subsection{Electrical application}

If a coating is needed to provide electrical insulation at high temperature, the obvious choice is an alkali free coating, since electrical conduction is attributed largely to the migration of alkali ions. On the other hand, if a coating is desired for the purpose of attaining useful electrical conductivity at temperature below $400^{\circ} \mathrm{C}$, it is logical to choose a conventional vitreous enamel coating containing significant amount of alkali ions. The desirable properties

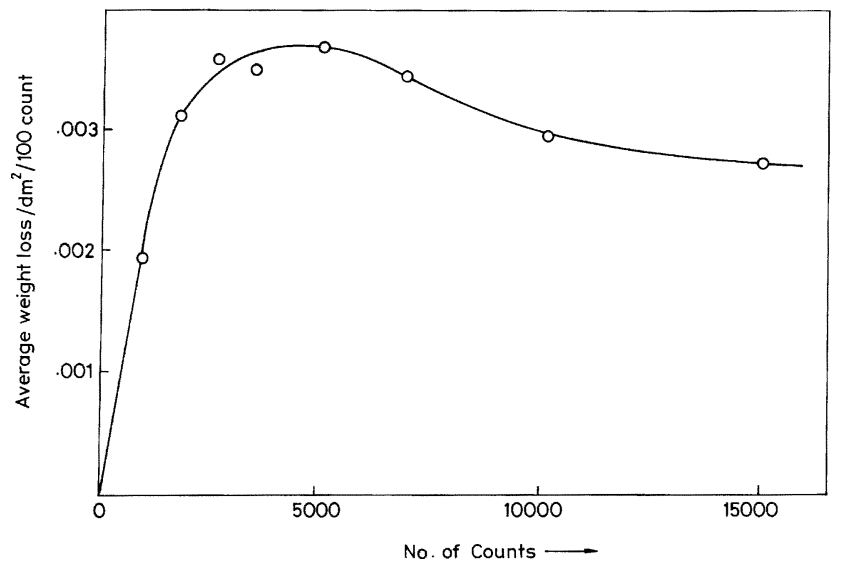

Figure 6. Variation of abrasion resistance of glass-ceramic coatings for mild steel with time.

Table 3. Domestic enamel coating vs industrial ceramic coating.

\begin{tabular}{|c|c|c|}
\hline Properties & Normal domestic enamel coating & Industrial ceramic coating \\
\hline Abrasion resistance & Withstands ordinary cleaning powders & Can be better than most metals \\
\hline Heat resistance & $\begin{array}{l}\text { Long term resistance to cooking temperature } \\
\text { up to } 300^{\circ} \mathrm{C}\end{array}$ & Resists $850^{\circ} \mathrm{C}$ and $1000^{\circ} \mathrm{C}$ for short period \\
\hline Corrosion resistance & Resistant to domestic acids and alkalis & Withstands most acids and alkalis \\
\hline Organic solvent & Totally resistant & Totally resistant \\
\hline Boiling water & Resistant & Available for water side of heat exchangers \\
\hline Thermal shock resistance & Resists rapid cooling from $500^{\circ} \mathrm{C}$ & Resists cooling from high temperature \\
\hline Longevity & Indefinite unless mechanically damaged & Very slowly attacked in extreme chemical environments \\
\hline
\end{tabular}


for an ideal enamelled steel board for application as an electrical insulator are shown in table 4 (CGCRI Training Manual 1993).

\subsection{Chemically resistant coating}

The chemical and chemical-metallugical industry today needs acid resistant coating materials having high linear coefficient of thermal expansion suitable for use in equipment which need to resist wider varieties of acids, alkalis, salts and solvents over higher ranges of concentration, temperature and pressure. However, large amounts of alkali oxides sharply reduce the acid resistance property of the coatings (Pevzner et al 1972). Highly corrosion resistant (Dutta 1998) vitreous coatings on steel transform it into a superior material of construction for

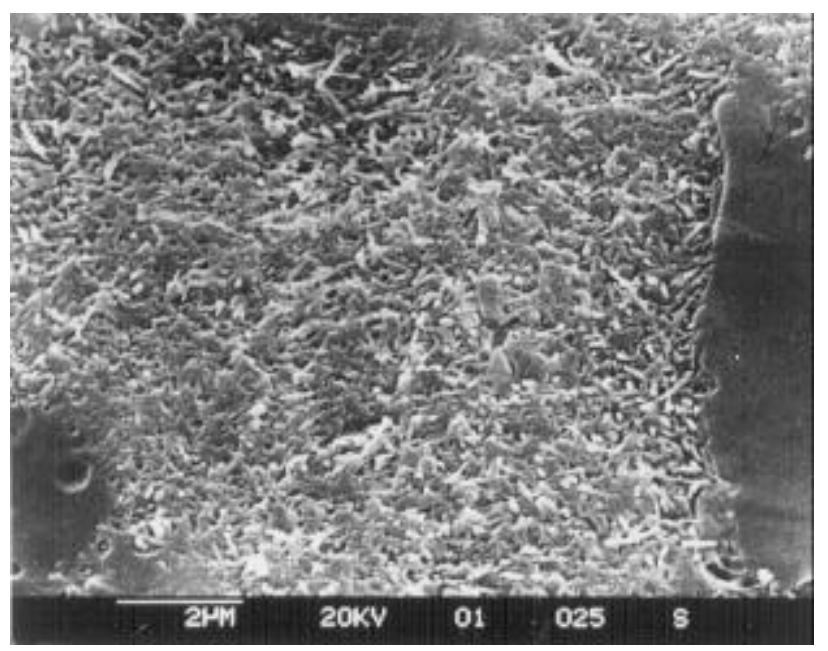

Figure 7. SEM micrograph of glass-ceramic coatings (before crystallization).

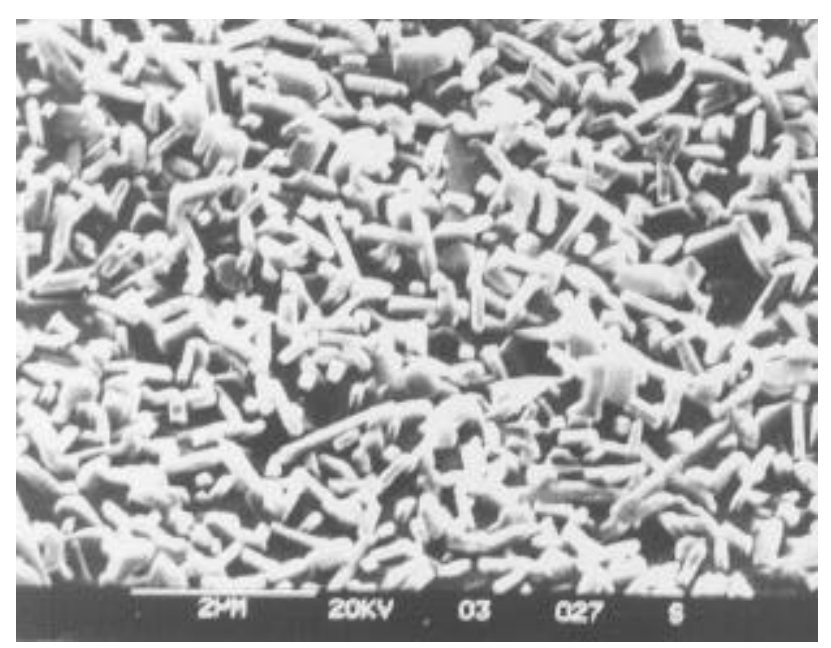

Figure 8. SEM micrograph of glass-ceramic coatings (after crystallization). chemical, pharmaceutical, oil, gas and allied industries. The oxides of titanium, zirconium, aluminium, magnesium, iron and tin increase the chemical stability of enamel coatings (Vargin and Zasukhina 1972). Table 5 shows the properties of the desired coatings (CGCRI Training Manual 1993).

\subsection{Abrasion resistant coating}

This is a new class of protective coating which has tremendous potential for engineering and industrial applications. It differs from conventional enamel coating due to the presence of a certain amount of finely dispersed crystal phases throughout the coating (effected by controlled heat treatment process) which results in high improvement of physical properties. Due to high mechanical strength and abrasion resistance properties, the crystallized coatings have a good potential for applications where abrasive action accelerates the failure of metals. The desirable properties of this group of coatings have been shown in table 6 (CGCRI Training Manual 1993).

Table 4. The desirable properties required for electrical applications.

\begin{tabular}{ll}
\hline Properties & \multicolumn{1}{c}{ Requirements } \\
\hline Mechanical & $\begin{array}{l}\text { Good enamel steel adhesion } \\
\text { Ability to withstand impact, abrasion and } \\
\text { vibration } \\
\text { Ability to withstand thermal cycling and } \\
\text { shock }\end{array}$ \\
Electrical & $\begin{array}{l}\text { Able to withstand } 3000 \mathrm{~V} \text { at } 150^{\circ} \mathrm{C} \\
\text { Resistivity }\left(10^{14} \mathrm{ohm} / \mathrm{cm}\right)\end{array}$ \\
High surface resistivity \\
Other requirements
\end{tabular}

Table 5. Properties of corrosion resistant glass-ceramic coating.

\begin{tabular}{ll}
\hline Properties & Results \\
\hline $\begin{array}{l}\text { Acid resistance (2 h boiling in 1\% } \\
\text { sulphuric acid) }\end{array}$ & $5 \mathrm{mg} \cdot \mathrm{dm}^{-2}$ \\
Coat thickness & $0 \cdot 15-0 \cdot 2 \mathrm{~mm}$ \\
$\begin{array}{l}\text { Adherence index (in PEI Adherence } \\
\text { Tester) }\end{array}$ & $>95 \%$ \\
Impact strength (Falling ball method) & $>20 \mathrm{~kg} \cdot \mathrm{cm}^{\circ}$ \\
$\begin{array}{l}\text { Thermal shock resistance } \\
\text { Boiling water resistance }\end{array}$ & $550^{\circ} \mathrm{C} \mathrm{for} 10$ cycles \\
& $30 \mathrm{mg} \cdot \mathrm{dm}^{-2}$ (Liquid) \\
Abrasion resistance (50,000 cycles in & $2-3 \mathrm{mg} \cdot \mathrm{dm}^{-2}$ (Vapour) \\
PEI Abrasion Tester) & \\
Surface finish & $\mathrm{Black} \mathrm{glossy} \mathrm{finish}$ \\
\hline
\end{tabular}


Table 6. Properties of abrasion resistant coating.

\begin{tabular}{|c|c|}
\hline Properties & Results \\
\hline $\begin{array}{l}\text { Abrasion resistance (loss in weight } \\
\text { value against } 50,000 \text { cycles) }\end{array}$ & $\begin{array}{l}\text { (a) } 1 \cdot 0-1 \cdot 2 \mathrm{mg} \cdot \mathrm{cm} \text { for mild steel and } \\
\text { stainless steel } \\
\text { (b) } 0 \cdot 6-0.8 \mathrm{mg} \cdot \mathrm{cm} \text { for nimonic alloy }\end{array}$ \\
\hline Vicker's hardness (Test load = 100 gm) & $900-1200 \mathrm{~kg} \cdot \mathrm{mm}^{-2}$ \\
\hline Impact strength (Falling ball method) & $22-25 \mathrm{~kg} \cdot \mathrm{cm}$ \\
\hline Thermal shock resistance & $\begin{array}{l}\text { (a) } 400^{\circ} \mathrm{C}(15 \text { cycles }) \text { for } \mathrm{M} / \mathrm{S} \\
\text { (b) } 600^{\circ} \mathrm{C}(10 \text { cycles }) \text { for } \mathrm{S} / \mathrm{S} \\
\text { (c) } 900^{\circ} \mathrm{C}(10 \text { cycles }) \text { for Nimonic }\end{array}$ \\
\hline $\begin{array}{l}\text { Acid resistance (boiling) } \\
\text { (a) } 6 \% \text { Citric acid } \\
\text { (b) } 11 \% \text { Hydrochloric acid } \\
\text { (c) } 11 \% \text { Sulphuric acid } \\
\text { (d) } 11 \% \text { Nitric acid } \\
\text { (e) Conc. hydrochloric acid } \\
\text { (f) Conc. sulphuric acid } \\
\text { (g) Conc. nitric acid } \\
\text { (h) Chrome plating solution }\end{array}$ & $\begin{array}{l}\text { (a) } 3-4 \mathrm{mg} \cdot \mathrm{dm}^{-2} \\
\text { (b) } 10-15 \mathrm{mg} \cdot \mathrm{dm}^{-2} \\
\text { (c) } 10-15 \mathrm{mg} \cdot \mathrm{dm}^{-2} \\
\text { (d) } 10-15 \mathrm{mg} \cdot \mathrm{dm}^{-2} \\
\text { (e) } 10 \mathrm{mg} \cdot \mathrm{dm}^{-2} \\
\text { (f) } 25 \mathrm{mg} \cdot \mathrm{dm}^{-2} \\
\text { (g) } 10 \mathrm{mg} \cdot \mathrm{dm}^{-2} \\
\text { (h) } 5-6 \mathrm{mg} \cdot \mathrm{dm}^{-2}\end{array}$ \\
\hline $\begin{array}{l}\text { Alkali resistance (loss in weight for } \\
2.5 \mathrm{~h} \text { boiling) in tetra-sodium pyro- } \\
\text { phosphate solution at } \mathrm{pH}=10\end{array}$ & $1-2 \mathrm{mg} \cdot \mathrm{dm}^{-2}$ \\
\hline
\end{tabular}

Table 7. Properties of high temperature resistant coating.

\begin{tabular}{|c|c|}
\hline Properties & Results \\
\hline Fusing temperature of the coating & $\begin{array}{l}\text { Depends on thermal limi- } \\
\text { tation of base metal but } \\
\text { generally varies from } 800- \\
1160^{\circ} \mathrm{C}\end{array}$ \\
\hline Coat thickness & $0.01 \mathrm{~mm}(10 \mu \mathrm{m})$ \\
\hline $\begin{array}{l}\text { Thermal shock resistance (heating } \\
\text { the sample up to their operating } \\
\text { temperature and quench in cold } \\
\text { water) }\end{array}$ & $\begin{array}{l}\text { No chipping even after } 10 \\
\text { cycles }\end{array}$ \\
\hline $\begin{array}{l}\text { Acid resistance of the coating } \\
\text { (hot chrome plating solution) }\end{array}$ & No visible reaction \\
\hline Adherence $\left(90^{\circ}\right.$ bending $)$ & $\begin{array}{l}\text { Only a trace of the coating } \\
\text { may chip off from the edges } \\
\text { at the convex side }\end{array}$ \\
\hline
\end{tabular}

\subsection{High temperature resistant coatings}

With the developments in aerospace technology, the need for formulation of special glasses and glass-ceramic coating materials that can withstand the action of high temperature under corrosive environments has increased. The high temperature resistant coating compositions are based on alkali free barium silicate glass compositions. The maturing temperature of such coatings on superalloys are fairly high (in the range of $1000-1200^{\circ} \mathrm{C}$ ). These coatings have been characterized by X-ray and SEM studies. Various properties of this group have been evaluated and presented in table 7 (Majumdar et al 1986).

\subsection{Thermal barrier coating (TBC)}

It is another kind of high temperature resistant coating which has recently been developed. The main objective of this coating is to provide thermal insulation to metallic components at elevated temperature especially for diesel, gas turbine and aero-engine applications. Improvement of thermal efficiency and reduction of the $\mathrm{NO}_{x}$ level in TBC coated piston heads of diesel engine have been studied (Bose et al 1997) and the thermal gradient between the substrate and the surface coating observed. The properties which have been evaluated are shown in table 8 (Majumdar and Jana 2000).

\subsection{Spall or anti-oxidation coating}

Spall or heat treatment protective coating provides a temporary protection to the metals from oxidation during long heat treatment schedule. Upon cooling, following the removal of the heat treated parts from the furnace, the coating spalls spontaneously leaving a bright, metallic, oxide free surface. The ability of coating material to prevent oxidation is largely due to the fact that the coatings which are in oxide state, do not undergo further oxidation at elevated temperature; they also form an effective barrier for diffusion of oxygen and for preventing carbonaceous gases from reacting with the base metal. This type of coating protects (Majumdar and Dutta 1998) the martensitic stainless steel against the loss $(\sim 3 \%)$ and doubles its hardness at $1100^{\circ} \mathrm{C}$. 
Table 8. Properties of thermal barrier coating.

\begin{tabular}{ll}
\hline Properties & \multicolumn{1}{c}{ Results } \\
\hline $\begin{array}{l}\text { Thermal endurance } \\
\text { (a) at } 800^{\circ} \mathrm{C} \pm 10^{\circ} \mathrm{C}(10 \text { minutes }\end{array}$ & 100 cycles (No damage) \\
standing at test temperature and 10 & \\
minutes at $\mathrm{RT}$ ) \\
(b) at $1000^{\circ} \mathrm{C} \pm 10^{\circ} \mathrm{C}(10$ minutes & 30 cycles (No damage) \\
standing at test temperature and 10 & \\
minutes at RT) & \\
Gradient obtained without cooling & $175-180^{\circ} \mathrm{C}$ \\
system at $1000^{\circ} \mathrm{C}$ & \\
Gradient obtained with dry cooling & $650-675^{\circ} \mathrm{C}$ \\
system at $1000^{\circ} \mathrm{C}$ & \\
Thermal shock resistance (from red & 100 cycles without any \\
hot condition at $1000^{\circ} \mathrm{C}$ to RT) & damage \\
Coat thickness & $750-800 \mu \mathrm{m}$ \\
$\begin{array}{l}\text { Abrasion resistance (in P.E.I. Abra- } \\
\text { sion Tester); loss in weight value in }\end{array}$ & $1 \cdot 10-1 \cdot 27$ \\
mg.cm ${ }^{-2}$ against 50,000 cycles & \\
\hline
\end{tabular}

\section{Testing and evaluation}

The testing of glass and glass-ceramic coated articles are very important and essential to the producers, suppliers and consumers for the following reasons: (i) to lower the production cost; (ii) to increase the productivity; (iii) to effect more reliable performance; (iv) to reduce wastage and (v) for expanding goodwill.

The ranges of product testing includes: (i) enamelware for domestic use; (ii) glass-ceramic coatings for engineering and industrial articles; (iii) sanitaryware and hospitalware and (iv) sign boards.

Recommended tests for engineering and industrial articles according to IS/ASTM/DIN specifications include: (i) abrasion resistance; (ii) heat resistance; (iii) resistance to chemical corrosion; (iv) thermal shock resistance; (v) impact resistance; and (vi) adherence index.

\section{Conclusions}

There have been many pushes and pulls in the surface engineering industry. There was a big boom after the second world war (1945). All traditional surface engineering techniques like electroplating, hot dip coatings, anodizing, organic paints, plastics etc made significant advances. During 70s and 80s, the future of electroplating seemed gloomy but with increasing demand in electronics, space, defence and other engineering industries, the commercial applications of deposition processes increased manifold. About $45 \%$ of total share of surface modification is done by industrial painting. Thus, glass and glassceramic coatings are not only new generation of coatings but also versatile engineering materials which increase the service life of different types of metallic substrates. They have a very potential and promising market and are very likely to replace industrial painting practices considerably.

\section{Acknowledgements}

The authors are thankful to Dr D Ganguli, CGCRI and all other members of Glass-Ceramic Coating Division, for various help.

\section{References}

Andrews A I 1962 Porcelain enamel (Illinois: The Garrard Press) pp. 123, 252, 306-315, 337-360

Bose P K, Beg R A, Ghosh B B, Das S K and Majumdar A 1997 Proc. 4th Asia-Pacific international symp. on combustion and energy utilization, Bangkok, Thailand, (Bangkok, Thailand: Department of Energy Development and Promotion, Ministry of Science, Technology and Environment) Vol. II, p. 919

Briggs J 1989 Technology and markets for inorganic coatings in Western Europe (UK: Forest \& Sullivan)

Burgel R B and Kvernes I 1986 Proc. conference on thermal barrier coating (Belgium: D Reidel Publishing Co.) p. 327

CGCRI Training Manual 1993 in Wear resistant ceramic coatings for industrial and engineering application (Calcutta: CGCRI) p. 3

Dutta S 1998 Bull. Mater. Sci. 21421

Hennicke H W and Pandel A 1991 The Vitreous Enameller 4227

Hocking M G, Vasantasree V and Sidky P S 1989 Longman scientific and technical (Essex: Longman)

Majumdar A and Ganguli D 1995 Trans. Ind. Ceram. Soc. 54 227

Majumdar A and Das S K 1996 Trans. Ind. Ceram. Soc. 55130

Majumdar A and Dutta S 1998 Proc. national seminar on indigenization and vendor development-98 (Koraput: Hindustan Aeronautics Ltd.) p. 58

Majumdar A and Jana S 2000 Mater. Lett. 44197

Majumdar A, Dutta S, Das S K, Biswas K K and Roy N 1986 Trans. Ind. Ceram. Soc. 4543

Maskal K A and White D 1986 International conference on wear (New Castle-upon-Tyne: Pergamon Press)

McMillan P W 1978 Glass-ceramics (London: Academic Press Inc.) pp. 11, 25-27, 29

Miller N S C 1988 The Vitreous Enameller 39129

Miller R A, Shinde S L, Olson D A and Joughe L C 1986 Ceram. Engg. \& Sci. Proc. 71032

Narang S K 1998 Proc. national workshop on surface engg. in corrosion control (Jamshedpur: Corrosion Protection Division)

Pevzner B Z, Dzhavuktsyan S G and Mishel V E 1972 Glass \& Ceramics 29245

Schmid T E and Heeht 1988 Ceram. Engg. Proc. 91089

Sen R, Dutta S, Das S K and Basu S K 1989 Wear 130249

Shaw K 1968 Technology of Enamels (ed. \& Trans.) V V Vargin (London: Maclaren \& Sons Ltd.) pp. 179-181, 183, 197-202, 204-206

Tong J, Zhang M, Jian M and Ren L 1998 J. Mater. Sci. Lett. 17523

Vargin V V and Zasukhina L Z 1972 Glass \& Ceramics 29387

Zubekhin A P, Thachev A G and Thacheva O N 1996 Glass \& Ceramics $\mathbf{5 3} 275$ 